\title{
Accountability of Bali Regional Officers in Applying Good Governance Principles
}

\author{
I.G.A.AG Dewi Sucitawathi Pinatih ${ }^{1}$ I Wayan Joniarta ${ }^{2}$, Ni Luh Yulyana Dewi ${ }^{3}$ \\ ${ }^{1}$ Universitas Pendidikan Nasional (email: iga_dewi@undiknas.ac.id), ${ }^{2}$ Universitas Pendidikan Nasional (email: \\ wayanjoniarta@undiknas.ac.id), ${ }^{3}$ Universitas Pendidikan Nasional (email: yulyanadewi@yahoo.com)
}

\begin{abstract}
Development in Bali is generally largely initiated, proposed, executed by the legislature, in this case the members of the Regional Representative Council, both the Provincial DPRD, Regency DPRD, Denpasar City DPRD. Conceptually, the legislature has the task of making policies, regulations and regional regulations (PERDA) in collaboration with executives. The fact is in Bali, it is precisely the people's representatives who sit in the DPRD dominating the planning process, and implementing policies such as submitting grants for both physical and non-physical development in the community. Submission of proposals for regional development is often bridged by legislative members, causing the existence and authority that the executive should have taken over by members of the legislature. Not infrequently this triggered the emergence of corrupt practices in the bureaucratic body. The purpose of this research is to find out how the accountability of Balinese officials in applying the principles of good governance. The research methods used were interview techniques, observation techniques, and documentation techniques. The results of this study were to obtain information about the accuracy of the implementation of the principles of good governance carried out by the legislature and executive in the Bali region.
\end{abstract}

\section{Keywords:}

accountability; regional officials; good governance

\section{Introduction}

The democratic governance system adopted by the Indonesian state after the reformation has created a competitive bureaucratic condition. Central and local governments are required to carry out their duties, functions and roles according to the concept of good governance. Some ethical values that are embedded in the concept of good governance such as a clean government that is a government that is free from elements of corruption, collusion, nepotism (KKN); professional governance, namely governance run by competent human resources (merit system); transparent government, namely digital-based government (online); and accountable government, that is, a government that implements a work ethic in accordance with its institutional functions (legislative, executive, judiciary). At the regional level, the value of democracy can be seen from the decentralized system that 
provides opportunities for regions to independently manage their potential (regional autonomy).

The development of an area is inseparable from the role of the regional government, and to realize the mission of the regional government requires cooperation, control (check and balance), good supervision conducted by the executive (Governor, Mayor, Regent) along with the legislative (Provincial DPRD, Regency DPRD) and judiciary (police, judge, prosecutor). The decentralized system adopted has fostered reform at the local level, by providing space for politics, regional financial management, and the utilization of regional resources for the benefit of local communities. So that it creates a new style of development in the area. The concept of decentralization is always associated with issues of efficiency and innovation. Because through decentralization will be able to cut several stages of bureaucracy.

Innovation means that it will create programs that better reflect the real needs of people in the region, so that full development is realized. Law No. 22 of 1999 concerning regional autonomy has created a state problematic, where the law opens opportunities for symptoms of regional non-compliance and or unilateral interpretation of various laws created by the central government. The regional autonomy law also creates a phenomenon, where the center of power is no longer in the executive's hands (executive heavy), but instead is in the hands of the legislative (legislative heavy) (Rahmanurrasjid, 2008). The decentralized system actually makes local government accountability better, which causes the government to be more optimal in providing services to the community. Some local government programs were created to improve community welfare such as grants and social assistance funds. Demands to increase the economic welfare of the community, sometimes lead to dysfunction of duties and authority of each of the main organs of government administration.

In providing social assistance funds (Bansos) in Bali, DPRD members play an important role in succeeding proposals proposed by the community. The role of DPRD members as initiators, facilitators, executors in several social assistance programs such as granting funds to repair Temples, places for improving infrastructure (Roads, Schools, Banjars, Tourism Objects) is vital. The importance of the role of a board member in the success of the social assistance program leads to increasingly fertile practices of corruption 
in the body of local officials. The desire to realize good governance is far from expectations, the principles of professionalism, transparency and accountability are clearly not reflected in the practices that have been carried out by local officials in Bali, especially members of the DPRD, in addition to the phenomenon of dominance by members DPRD on executive authority in executing grant assistance to the community.

The conceptual study used in research is accountability which has the meaning of accountability to the person or agency that gives authority to carry out a program, as said by Haris (2007: 349), that, accountability is the obligation of individuals or authorities entrusted to manage public resources and related to it to be able to answer matters relating to fiscal, managerial and program policies. According to Djalil (2014: 63) the definition of accountability is an ethical concept that is close to public administration of government (government executive, parliamentary and judicial institutions) which has several meanings, among others, this is often used synonymously with concepts such as those can be accounted for (responsibility), which can be questioned (answerbility), which can be blamed (blameworthiness) and who have a connection with expectations can explain one aspect of public administration / government (Rahmanurrasjid, 2008).

According to Adisasmita (2011: 30) accountability is an instrument of responsibility for the success and failure of the main tasks and functions and organizational mission. So that accountability basically means the realization of the obligation of a person or group in an organizational unit to account for every activity in the management and control of resources and implementing policies that are mandated to it, in order to achieve the planned objectives. The research will analyze the accountability of leadership carried out by the legislature (DPRD) and the executive (Governor, Mayor) to prevent abuse of power by examining the authority possessed by each institution.

The accountability dimension Ellwood (2003: 371) in (Rahmanurrasjid, 2008) suggests the following four dimensions of public accountability:

a. Honesty and Law accountability

Honesty accountability is related to the avoidance of abuse of authority, whereas legal accountability is related to the existence of guarantees of compliance with laws and other regulations required in the use of public resources.

b. Process Accountability 
Process accountability is related to procedural problems used in assignments. Have you fulfilled the adequacy of accounting information systems, management information systems and administrative procedures? Process accountability is manifested through the provision of public services that are fast, responsive, and inexpensive. Process accountability relates to the methods and operating procedures of a system that transforms inputs into outputs. Process accountability emphasizes that some goals may not be measured and replaced directly, but instead presents how activities are directed towards achieving the goals.

c. Program Accountability

Program accountability is related to the problem of achieving goals (effectiveness) and considering alternative programs that provide optimal results with minimal costs. Program accountability is related to individual units and bureaucrats who carry out joint activities to achieve program effectiveness.

d. Policy Accountability

Policy accountability is related to the issue of government accountability to the public.

The conceptual study used next is the concept of good governance. Good governance is an implementation of solid and responsible development management that is in line with the principles of democracy and an efficient market, avoiding misallocation of investment funds and preventing corruption both politically and administratively, carrying out budgetary discipline and creating legal and political frame work for growing business activities. Good Governance is also interpreted as a key to providing public services by ensuring quality management (Rahman, 2016). The discussion in the concept of good governance discusses accountability, where accountability means the accountability of the supervisor to his staff, because it is given the authority of the government to take care of some affairs and interests in the institution. Each supervisor must be responsible for all policies, actions and neutrality of attitudes while serving in the institution. So that governance is very closely related to the growth and development of a country (Dayanandan, 2013). 
According to the United Nations Development Program (UNDP) further states the characteristics of good governance (Hetifa Sj, 2003):
a. All inclusive, transparency and responsibility, effective and fair.
b. Guaranteeing the rule of law.
c. Ensure that political, social and economic priorities are based on community consensus.
d. Paying attention to the interests of the poorest and weakest in the decision making process concerning the allocation of development resources.

Through understanding the concepts of accountability and good governance, it will be seen the quality of performance performed by local officials, especially in Bali. The problem in this study is to discuss the issue of accountability related to the accountability of the authority possessed by the legislature (DPRD) in Bali to the development program that should be driven more by the executive agency (Regional Government).

\section{Methods}

The research method used is descriptive qualitative. The research location took a sample in the city of Denpasar, Tabanan regency, Klungkung regency. The type of data used is primary and secondary data. Primary data obtained from observations, interviews, and documentation. While secondary data is obtained from books about the concepts of accountability and good governance, scientific journals, and the official website of local government agencies. The research informant selection technique uses purposive sampling, with the aim of extracting accurate information, clearly through credible sources.

\section{Results and Discussion}

Based on the laws and regulations, DPRD members have 3 functions, namely legislation, budgeting, and supervision. Legislation function is a function to make regional regulations together with the Regional Head; budget function is a function to discuss and approve the Regional Budget Draft (RAPBD) with the Regional Head; the oversight function is a function to oversee the implementation of regulations and regional budgets. The regional autonomy system adopted by Indonesia, in some areas such as Bali has enriched 
corrupt practices carried out by regional officials, especially in implementing social assistance programs (social assistance) to the community. In addition to corruption, the authority possessed by the executive in deciding and executing policies has begun to be minimized due to the increasingly strong power possessed by the legislative body, so it is not surprising that the number of people competing to run for membership in the DPR and DPRD exceeds the candidates for executive officers.

The dominance of authority carried out by the legislature (DPRD) in the case of social assistance has occurred a lot, both in the city of Denpasar, Tabanan, and Badung. In the social assistance program, DPRD members act as facilitators between the community and the local government (Governor, Mayor, Regent), where the DPRD is tasked with initiating, proposing, determining the type of assistance to the amount of money to be obtained by the community. According to Radar Bali sources, DPRD members who should have served as facilitators should bring proposals submitted by community groups addressed to the Governor of Bali and subsequently the proposals were selected and verified by the Regional Organization (OPD). Proposals for proposing infrastructure improvements will be directed to the Public Works Agency.

If the proposal is deemed feasible, then a field inspection will be conducted. After being declared to have passed the due diligence, the OPD will make recommendations, which later the proposal program will automatically appear in the APBD. In reality, DPRD have plotted the amount of money and allotment of grants to the community group (quoted from jpnn.com). In this case DPRD participate in initiating proposal proposals, allocation of grants, nominal figures to play a role in fighting for the passage of proposals submitted without regard to the authority of other institutions. The social assistance fund is evidence of the amount of power possessed by legislators so that in some cases it is not uncommon to lead to corruption cases.

An example of a case that occurred in Klungkung, according to one of Nusa Penida community leaders, the Chairperson of the Klungkung Regency DPRD is indicated to have committed corrupt practices, where the board member proposed a social aid proposal for Dadia Anya Kenceng Temple in Banjar Cubang, and it turned out that the construction of the Temple had never been carried out at all (quoted from metrobali.com). Corruption cases carried out by regional officials (DPRD) related to social assistance increasingly fade the 
value of bureaucratic accountability. Accountability is conceptually defined as the accountability of duties and functions that have been regulated in the law. Basically, a member of the council has legislative, budgetary, and supervisory duties. In reality in society, many board members overstep their authority, and tend to dominate and take over the work that is supposed to be done by the executive. One of them is in the matter of development, most of the physical development in the community is fought by members of the council such as repairing Temples, repairing Roads, renovating Banjars, Repairing Waterways (Gutters), repairing School Buildings.

Macro to micro development was also carried out by board members, for example donations of PKK uniforms. In Denpasar, several Banjars have been given donations of clothes, which are used for traditional activities. So when asked, the community will surely answer that what they get is come from DPRD contribution. Even worse when the legislative general election arrives, all members of the council will compete to attract the sympathy of the public with various offers of assistance programs. Not infrequently the members of the council will be in the name of Social Assistance (Bansos) to perpetuate political goals, and perpetuate corrupt practices.

Social assistance funds are often used as an excuse to intervene in executive authority. The phenomenon that occurs is the abuse of power, that is, those who create regulatory products, initiate community programs, determine the amount of money to be received, and lobbying with the executive are also determined by the board members. The demand to create governance that reflects the concept of good governance is also caused by the level of public confidence in the members of the board is reduced. Democracy has paved the way for the community to increasingly supervise and supervise the duties of regional officials so as not to deviate from their original purpose. In addition, one of the sounds of the concept of good governance is transparency and public participation in order to improve the people's economic welfare (Ekundayo, 2017).

According to the State Administration Agency (LAN), governance is the process of implementing state power in providing public goods and services. And to achieve excellent public services, the government and regional officials are required to understand the functional aspects, namely working to serve the community effectively and efficiently. The accountability of local officials, especially the social assistance case, is very contrary to the 
reality in the community, there are 59 social assistance found in Klungkung, and one of them is the case of project manipulation carried out by individual members of the board. Sometimes manipulative social assistance involves several parties, namely the community and local government. For the time being, the performance of regional officials in Bali has not yet been maximized, because from a number of cases it has been proven that there is a dominance of board members in the success of development programs.

The decentralized system implemented by Indonesia must be balanced with the performance, excellent service quality of regional officials. The central government has given complete trust in the administration of the wheels of government at the regional level, one of which is the economic development of the community. Regional officials in Bali (council members) have clearly committed abuse of power, through the social assistance program, grants by board members seeking loopholes to engage in corrupt practices. Sometimes corrupt practices involve both the executive and the community. Accountability is related to responsiveness (quoted from https://siteresources.worldbank.org), transparency as a main feature of the concept of good governance, without the disclosure of information to the public, it is impossible for local officials in Bali to be able to carry out their duties and functions according to the laws and regulations. So in this case supervision from both the community and executive is needed for the work carried out by regional officials (DPRD).

\section{Conclusion}

The accountability of regional officials in Bali does not yet reflect the principle of transparency, professionalism in carrying out their authority. The trend that occurs is a shift in the center of power from the executive and legislative branches, and this is what causes the influence of members of the council of community life. The dominance of board members can be seen in several social activities such as grants, and social assistance that is used as a means to establish influence both politically and economically.

\section{References}

Adisasmita, Rahardjo. (2011). Manajemen Pemerintah Daerah. Yogyakarta : Graha Ilmu.

Dayanandan, R. (2013). Good Governance Practice for Better Performance of Community Organizations - Myths and Realities!!. Journal of Power, Politics \& Governance, Vol. 1 
No. $1, \quad 2013 . \quad$ December Retrieved from

http://jppgnet.com/journals/jppg/Vol_1_No_1_December_2013/2.pdf.

Djalil, Rizal. (2014). Akuntabilitas Keuangan Daerah Implementasi Pasca Reformasi. Jakarta: PT Semesta Rakyat Merdeka.

Ekundayo, Woleola J. (2017). Good Governance Theory and the Quest for Good Governance in Nigeria. International Journal of Humanities and Social Science. Volume 7 • $\begin{array}{llllll}\text { Number } & 5 & \bullet & \text { May } & 2017 . & \text { Retrieved }\end{array}$ http://www.ijhssnet.com/journals/Vol_7_No_5_May_2017/21.pdf.

Haris, Syamsuddin. (2007). Desentralisasi dan Otonomi Daerah (Desentralisasi, Demokratisasi E Akuntabilitas Pemerintahan Daerah). Jakarta: LIPI Press.

Rahman, Md. Lutfor. (2016). Governance and Good Governance: A Theoretical Framework. Public Policy and Administration Research. Vol.6, No.10, 2016. Retrieved from https://pdfs.semanticscholar.org/620b/33fefa8dd2e747d50a076bc85c17cd4538a4.pdf.

Rahmanurrasjid, Amin. (2008). Akuntabilitas dan Transparansi dalam Pertanggungjawaban Pemerintah Daerah untuk Mewujudkan Pemerintahan yang Baik di Daerah. 1-155.

Sumarto Hetifa Sj. (2003). Inovasi, Partisipasi dan Good Governance. Bandung: Yayasan Obor Indonesia.

https://siteresources.worldbank.org/PUBLICSECTORANDGOVERNANCE/Resources/Acco untabilityGovernance.pdf. Accountability in Governance.

https://metrobali.com/bansos-dikembalikan-ketua-dprd-klungkung-jangan-cuci-tanganpenegak-hukum-jangan-tutup-mata/. Bansos Dikembalikan, Ketua DPRD Klungkung Jangan Cuci Tangan, Penegak Hukum Jangan Tutup Mata.

https://www.jpnn.com/news/begini-modus-anggota-dewan-cari-tambahan-dana-hibah. Begini Modus Anggota Dewan Cari Tambahan Dana Hibah. 